\title{
Correction to: Trust in the investor relationship marketing of startups: a systematic literature review and research agenda
}

\author{
Manuel Kaiser ${ }^{1,2}$ (D) Elisabeth S. C. Berger ${ }^{1}$
}

Accepted: 23 May 2021 / Published online: 22 September 2021

(c) The Author(s) 2021

\section{Correction to: Management Review Quarterly (2021) 71:491-517 https://doi.org/10.1007/s11301-020-00191-9}

The article Trust in the investor relationship marketing of startups: a systematic literature review and research agenda, written by Manuel Kaiser and Elisabeth S. C. Berger, was originally published Online First without Open Access. After publication in volume 71, issue 2, page 491-517 the author decided to opt for Open Choice and to make the article an Open Access publication. Therefore, the copyright of the article has been changed to (CThe Author(s) 2020 and the article is forthwith distributed under the terms of the Creative Commons Attribution 4.0 International License, which permits use, sharing, adaptation, distribution and reproduction in any medium or format, as long as you give appropriate credit to the original author(s) and the source, provide a link to the Creative Commons licence, and indicate if changes were made. The images or other third party material in this article are included in the article's Creative Commons licence, unless indicated otherwise in a credit line to the material. If material is not included in the article's Creative Commons licence and your intended use is not permitted by statutory regulation or exceeds the permitted use, you will need to obtain permission directly from the copyright holder. To view a copy of this licence, visit http://creativecommons.org/licenses/by/4.0/.

Open Access funding enabled and organized by Projekt DEAL.

The original article can be found online at https://doi.org/10.1007/s11301-020-00191-9.

Manuel Kaiser

manuel.kaiser@iao.fraunhofer.de

Elisabeth S. C. Berger

elisabeth.berger@uni-hohenheim.de

1 Entrepreneurship Research Group, University of Hohenheim, Wollgrasweg 49, 70599 Stuttgart, Germany

2 Fraunhofer Institute for Industrial Engineering IAO, Nobelstraße 12, 70569 Stuttgart, Germany 
Open Access This article is licensed under a Creative Commons Attribution 4.0 International License, which permits use, sharing, adaptation, distribution and reproduction in any medium or format, as long as you give appropriate credit to the original author(s) and the source, provide a link to the Creative Commons licence, and indicate if changes were made. The images or other third party material in this article are included in the article's Creative Commons licence, unless indicated otherwise in a credit line to the material. If material is not included in the article's Creative Commons licence and your intended use is not permitted by statutory regulation or exceeds the permitted use, you will need to obtain permission directly from the copyright holder. To view a copy of this licence, visit http://creativecommons.org/licen ses/by/4.0/.

Publisher's Note Springer Nature remains neutral with regard to jurisdictional claims in published maps and institutional affiliations. 